\title{
A HYDRO-INFORMATIC APPROACH FOR ESTIMATION OF DESIGN FLASH-FLOOD IN BARGI DAM CROSS-SECTION OF NARMADA RIVER, INDIA
}

\author{
Gurveek S. Maan ${ }^{1}$, Jagadish P. Patra ${ }^{2}$, Ripudaman Singh ${ }^{{ }^{*}}$ \\ ${ }^{2}$ National Institute of Hydrology, Roorkee 247667, India \\ *Corresponding author: ripudaman.17178@|pu.co.in \\ Received: December 315t, 2019 / Accepted: May 10 , 2020 / Published: July 15t, 2020 \\ https://DOl-10.24057/2071-9388-2019-178
}

'Department of Geography, School of Humanities, Lovely Professional University, Phagwara 144411, Punjab, India

\begin{abstract}
Estimation of design flood is imperative for hydraulic designs of spillways and various other water resources development projects as well as very essential for flood risk assessment. The objective of the present study is to apply Geographical Information System (GIS) supported hydro informatics approach for estimation of design flash-flood in Bargi dam cross-section. A criterion used for estimation of design flash flood is validated by central water commission (CWC). A hydrologic modelling software (HEC-GeoHMS) is used for the delineation of basin characterises for simulation of the precipitation-runoff process of the dendritic basin system. The SUH (Synthetic Unit Hydrograph) and flood hydrographs for 25, 50 and 100 year return periods are computed along with time distribution curve which can be used to derive the time distribution co-efficient of storm rainfall in the sub-basins for the rainstorm of any duration. It is observed in this research that the peak characteristics of the design flash-flood are more perceptive to the various design storm pattern. It is demonstrated that flood hydrographs are important in flood-risk management. The results attained exhibit the capability of the flood hydrograph to describe the effects of different hydraulic systems.
\end{abstract}

KEY WORDS: Basin delineation, Synthetic Unit Hydrograph, Flood Hydrograph, Design Flood, Time distribution curve, HEC-GeoHMS

CITATION: Gurveek S. Maan, Jagadish P. Patra, Ripudaman Singh (2020). A Hydro-Informatic Approach For Estimation Of Design Flash-Flood In Bargi Dam Cross-Section Of Narmada River, India. Geography, Environment, Sustainability,

Vol.13, No 2, p. 104-114

https://DOl-10.24057/2071-9388-2019-178

ACKNOWLEDGEMENTS: Major limitation of the present research is that it is based on the data and study conducted in July 2011. Extending its comparison and changes taking place from that point of time to the later periods would be taken in the upcoming researches. Present paper is part of various studies carried out at National Institute of Hydrology (NIH), Roorkee, India. Researchers acknowledge the data provisions for this publication from NIH and are thankful for this collaboration and taking such collaborative researches in future as well.

Conflict of interests: The authors reported no potential conflict of interest.

\section{INTRODUCTION}

The study related to the safety of a structure in flash flood event is very crucial and need to be carried out at regular intervals. The hydrograph of extreme floods is valuable information for any hydrologic design. A most important parameter is the peak flood for better assessment of flood-related studies. Design flood studies are used to assess maximum flood that a hydraulic structure can bear. In design flood estimation a prominent concept of return period is used with non-exceedance probability. Giuliano et al., 2009 explained various methods such as empirical method, hydrograph technique, rational method, and flood frequency analysis to compute peak flood. The frequency analysis method is generally incorporated to calculate flood for a specific return period. In the case of inadequacy of primary data, frequency analysis recorded storm data is made and the storm of a particular frequency is applied to unit hydrograph for deriving design flood (Rowe et al. 2018). India is divided into 7 zones and 26 hydro-meteorological homogeneous sub-zones by Indian Meteorological
Department in association with Central Water commission and for each zone-specific flood estimation guidelines are formed for 25, 50 and 100 years return period (CWC 2002). The Bargi Dam on river Narmada is one of a series of 30 dams designed by the Central Water and Power Commission and was developed for creating irrigation and generating hydroelectric power for the country (CWC 2010). The transformation of rainfall into runoff has been a wide research topic and problem for hydrologists. To estimate and compute this difference many method, techniques, formulae has been tried and used with physiographic and climatic characteristics. Bernard's (1935) model was the first step to estimate unit hydrograph from watershed characteristics. Snyder (1938) derived a set of formulas relating to the physical geometry of watershed to three basic parameters of the unit hydrograph. Clark (1945) created a technique to compute the unit hydrograph of any desired unit period. The shape and channel slope create the peak of the instantaneous unit hydrograph (IUH) which is a function of watershed length Taylor and Schwarz (1952). According to Minshall (1960), the unit hygrograph's peak flow and 
time are dependent upon storm and rainfall intensity. Then Nash (1957) develops a model that has two parameters ( $\mathrm{n}$ and k). Nash explained these two parameters as relating to the first and second moment off unit hydrograph about the origin. But these two parameters were calculated from the watershed characteristics. Then Boyd (1978, 1982) developed a linear watershed boundary network (LWBN) to estimate the unit hydrograph from and hydrological properties of the watershed. National Institute of Hydrology (1985) has been done a regional unit hydrograph study for the Narmada basin from the Clark model. For this HEC-1 package was used (HEC-GeoHMS Reference Manual 2010; Parhi et al. 2012). Janusz Zelazinski (1986) gave a method for estimating flow velocity. This relation was between velocity and peak discharge. But this was the trial and error method to estimate the maximum value of velocity for each flood event. Rodriguez-Iturbe (1979, 1982 and 1997) gave the potential application to develop a unit hydrograph. According to him the effect of climatic variation is incorporated by having a dynamic parameter velocity in the formulation of the geomorphological instantaneous unit hydrograph (GIUH). By using manning's equation Panigrahi (1991) developed a system of computing velocity. GIUH approach is developed by Yen et al. (1997) on two hilly catchments in the eastern United States in Illinois. Bhaskar et al. (1997) derived GIUH from watershed geomorphological characteristics with the Nash model using ARC/INFO GIS for twelve watersheds in a big sandy river basin in eastern Kentucky. Which model he used was watershed hydrology simulation (WAHS). Maidment et al. 1996, Jenson and Domingue 1988, Maidment 2002 and Olivera and Maidment 1999 used DEM data to drive GIUH for three mountain basins in Italian Alps. Then Lee K. T. (1998) developed a design hydrograph by DEM with the help of geographic runoff simulation.

Many regional and national agencies apply the concept of Probable Maximum Precipitation or Flood (PMP or PMF) instead of statistical approaches for large dams (WMO 2009). There are four approaches to acquire synthetic design hydrograph (SDH): Synthetic Unit Hydrograph (SUH), Traditional Unit Hydrograph (TUH), Statistical Method (SM) and Typical Hydrograph (TH). In last two methods frequency analysis approach are followed to attain SDH Yue et al. (2002). Sauquet et al. (2008) established a 'representative hydrograph', attained by standardizing the dimensionless hydrographs $\mathrm{Q}(\mathrm{t}) / \mathrm{Qp}$ middling around the peak position. Mediero et al. 2010; Xiao et al. 2009, examined that it is very imperative to evaluate the shape of flood hydrograph and flood volume to prevent flood damage and designing hydraulic structures. Rosbjerg et al. 2013 also determined the magnitude of flood peak resultant to a specific return period during flood estimation. Design flood hydrograph plays a very vital contribution to calibrate physical properties of a flood occurrence for any particular return period and to obtain the event rarity through statistical information (Serinaldi and Grimaldi 2011). Parkes and Demeritt 2016; Nakamura and Oki, 2018 have shown estimation of design flood below definite return period is of major concern for flood studies, such as developing flood management and mitigation scheme, designing hydraulic structure. Probabilistic and deterministic methods are two approaches which is primarily used for design flood estimation (Smithers 2012; Rogger et al. 2012). Probabilistic approach considers the occurrence of flood events and on other side deterministic approach is based on rainfall data and some basin processes. The calibration of design is a very time taking process in geomorphic parameter measurement on topographic maps. This study is performed for peak flow analysis in an un-gauged watershed. The design storm is applied to the geomorphic runoff simulation model to obtain the design hydrograph (NIH 1997, 1998). In the science of hydrology, the time of 1900-1930 was empirical. The intensity of rainfall can be obtained from RainfallIntensity - Duration-Frequency curves, if the information is available. Current criteria for design flood estimation are given by the Central Water Commission (CWC) and Bureau of Indian Standard (BIS). The method of design flood was headed by Dr. A. K. Khosla with a team of engineers. And they had recommended that design discharge should be a maximum flood on record for a period not less than 50 years. They also suggested that in the case where data is not available in that situation design floods should be decided on the bases of hydro meteorological data.

Using this formula CWC and IMD have published flood estimation report for 26 subzones of India like Lower Ganga Subzone 1(g), upper Narmada and Tapi subzone 3(c) which is indicated in figure 1. This study is conducted to estimate design flood at the Bargi dam cross-section with these objectives: (a) Delineation of basins up to Bargi dam and estimation of catchment characteristics (b) Estimation of synthetic unit hydrographs for different delineated subbasins and (c) Estimation of flood hydrographs for various return periods $(25,50,100$ years) at the Bargi dam crosssection.

\section{DATA AND METHODOLOGY}

\section{Study Area and Data Availability}

The Narmada, also known as Rewa is one of the largest rivers in India. It bifurcates North India and South India as flowing westward by covering 1,312 km and drains into Gulf of Cambay (Khambat) into the Arabian Sea. The Narmada basin lies between Vindya and Satpura ranges by covering an area of $98,796 \mathrm{~km}^{2}$ lying on the northern extremity of the Deccan Plateau. The Bargi dam on river Narmada is of 69 $\mathrm{m}$ height and $5.4 \mathrm{~km}$ length. The water spreading is of the reservoir is over $267.97 \mathrm{~km}^{2}$ with about $75 \mathrm{~km}$ in length and $4.5 \mathrm{~km}$ width. The basin area is around $14,556 \mathrm{~km}^{2}$. In Basin Atlas, CWC 2014, the Narmada Basin is divided into 3 Subbasins viz. Narmada Upper, Narmada Middle and Narmada Lower Sub-basin which are shown in figure 2. Basin area up to Bargi Dam in Narmada Upper Sub-basin is considered as a study area for computation of various basin characteristics.

SRTM 90 m resolution DEM which is developed by NASA is considered in this study to capture the morphological characteristics of drainage basin. Accuracy at $90 \mathrm{~m}$ resolution is detailed enough to capture drainage basin characteristics. The more specific aim of this paper is to estimate design flash-flood, for which only SRTM DEM data are currently available. The spatial resolution of SRTM DEM is analysed and validated by Smith and Sandwell, 2003. The SRTM 90 m (3-arc seconds) was downloaded from http://www.cgiar-csi.org/ on July, 2010. Average rainfall is collected from the Indian Meteorological Department (IMD) for rainfall level analysis for three rain gauge stations covering proposed plant area. The topographical survey was carried out in the proposed plant field, and cross-section of drains was also calculated. The bathymetry is built from surveyed contours, SRTM DEM and spot height of Survey of India (SOI) toposheet.

\section{METHODOLOGY}

This research computes design flash flood to estimate flood hydrograph of at project site in Narmada River using HEC HMS model. The synthetic unit hydrographs are derived from basin characteristics of the study area and flood hydrographs for 25, 50 and 100 year return periods 


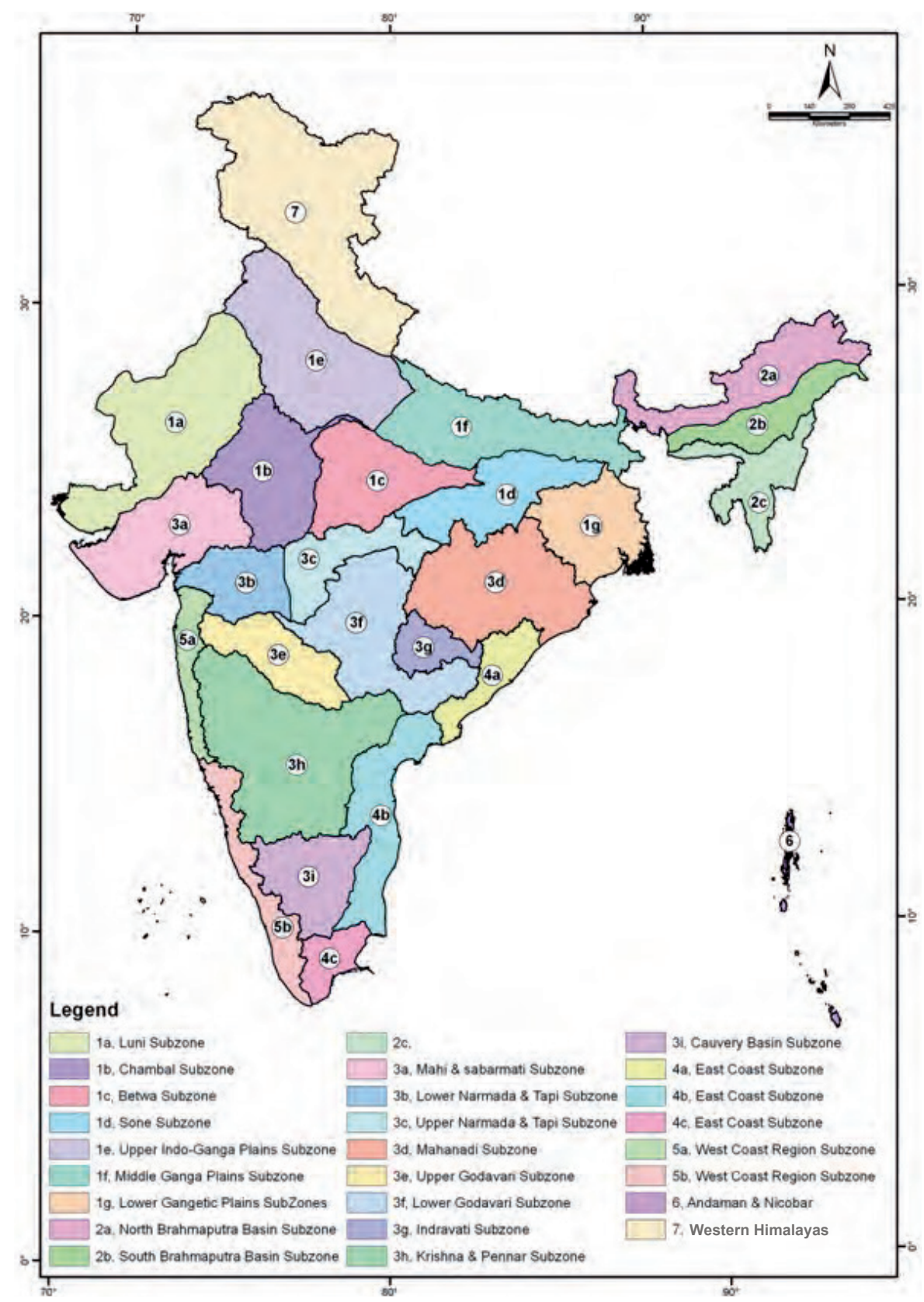

Fig. 1. Hydrological Zone Map of India

Source: CWC (Central Water Commission)

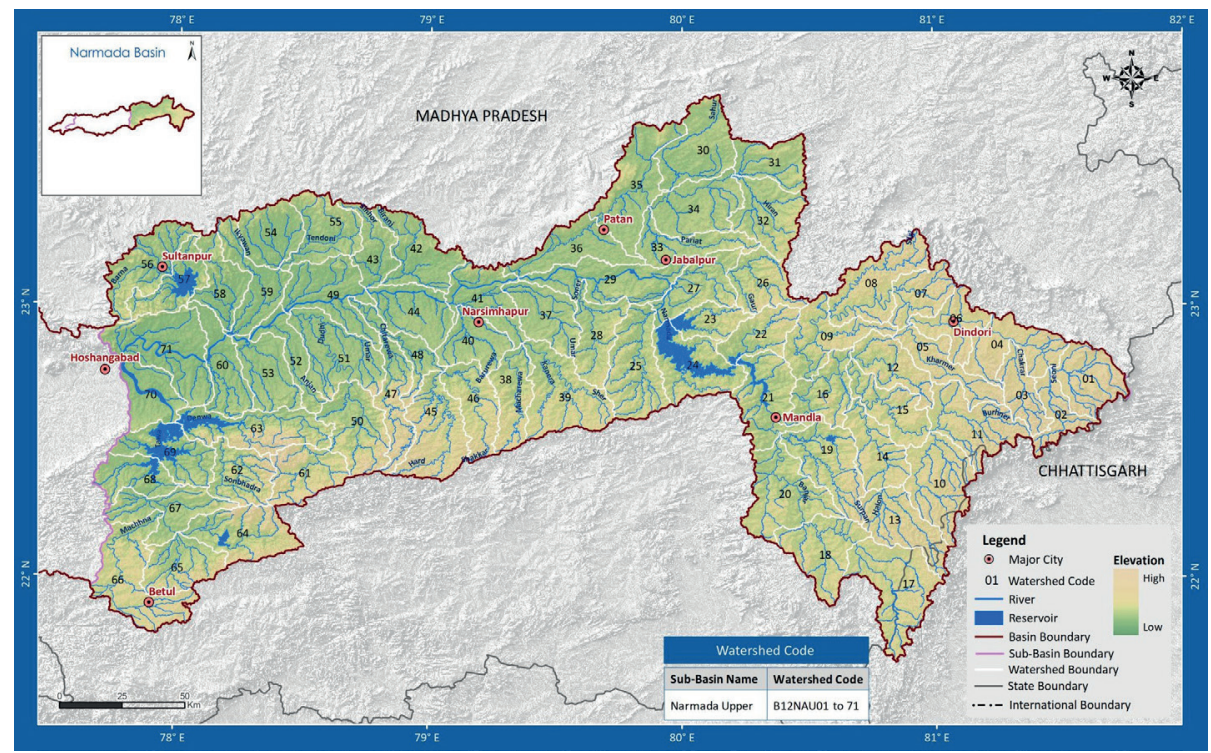

Fig. 2. Upper Narmada Sub-Basin (Sub-Zone 3c)

Source: CWC (Central Water Commission) 
are computed for Bargi dam situated on Narmada River. The basin area up to the Bargi dam is divided into five subbasin and synthetic unit hydrographs for each sub-basins are derived from the basin characteristics estimated using Arc GIS and Arc Hydro tools. A hydrologic model is setup in HEC-HMS for estimating flood hydrographs at outlet of each sub-basin and finally at the project site by hydrologic flood routing through the two reaches.

\section{Basin Delineation}

HEC-Geo HMS software is used for the delineating basin area of the Bargi dam from the SRTM DEM. There MSS image is used to identify land use and land cover pattern. The DEM is projected to the UTM projection system in ArcGIS before processing with HEC-Geo HMS (HEC-GeoHMS Reference Manual 2010; Parhi et al. 2012). A basin is all the land area that topographically drains surface water to a particular point of interest (outlet), often a water body such as a stream, lake or reservoir.

\section{Project Setup}

After terrain processing, layers of drainage network and polygon layers of all small basins are obtained. In this step outlet of the basin is defined and HEC-Geo HMS automatically copies all the terrain prepossessing data for the area upstream of the outlet location (HEC-GeoHMS Reference Manual 2010; Parhi et al. 2012). Thereafter using basin processing tools, sub-basin and stream networks can be subdivided and merge to meet the study objectives. In this study the Bargi dam site is selected as the outlet and the corresponding project area is delineated for further basin processing. The DEMs (digital elevation models) of the study areas were processed using HEC-GeoHMS, an ArcView GIS extension for catchment delineation, terrain pre-processing, and basin processing. The research methodology is explained in fig. 3.

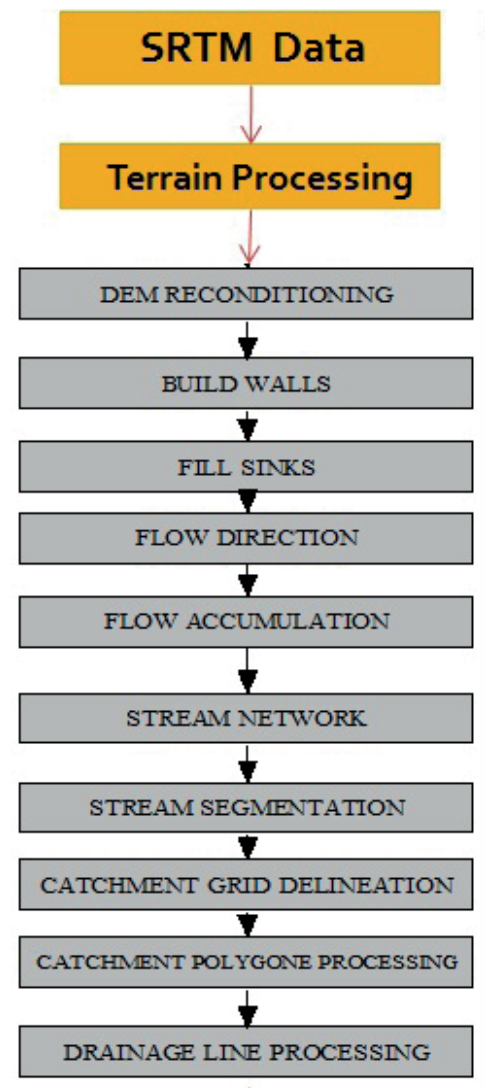

\section{Basin Processing}

After completion of terrain processing and project set up the projected area with projected points are established. In this step polygon layer for multi basins and drainage network layer are generated. The different tools allow visualizing delineation results, assessing outcomes, and accepting or denying the resulting delineation. In basin processing, different sub-basins are merged and divided into a total of 5 sub-basins each having an area less than $5000 \mathrm{~km}^{2}$.

\section{Stream and Sub-basin Characteristics}

After finalizing stream and sub-basin delineation, various physical characteristics can be extracted. Fig. 3 shows the flow chart of various steps involved in this process. First, the river length for selected or all routing reaches in the river layer are computed and then the river slope is calculated. From the river slope, elevation and slope of the river are calculated for downstream and upstream. After getting river length and slope, the longest flow path is calculated for each basin. It is one of the physiographic parameters to draw a unit hydrograph. It computes the longest flow length in every sub-basin, upstream elevation, downstream elevation, and slope between the endpoints. Then, the average basin slope is computed for all the five basins. It took average basin slope value from a slope grid. It is also a necessary parameter to draw a unit hydrograph. Basin centroid is computed because based on its interactive longest flow path are further considered. For calculation of centroid normally four methods are recommended. Three methods may be estimated basin centroid based on different algorithms and the fourth method is user-defined. In this research, the first method (center of gravity method) is used to extract basin centroid. Based on basin centroid, centroid elevation is calculated. And After this process, the last physiographic parameter, the centroidal flow path is

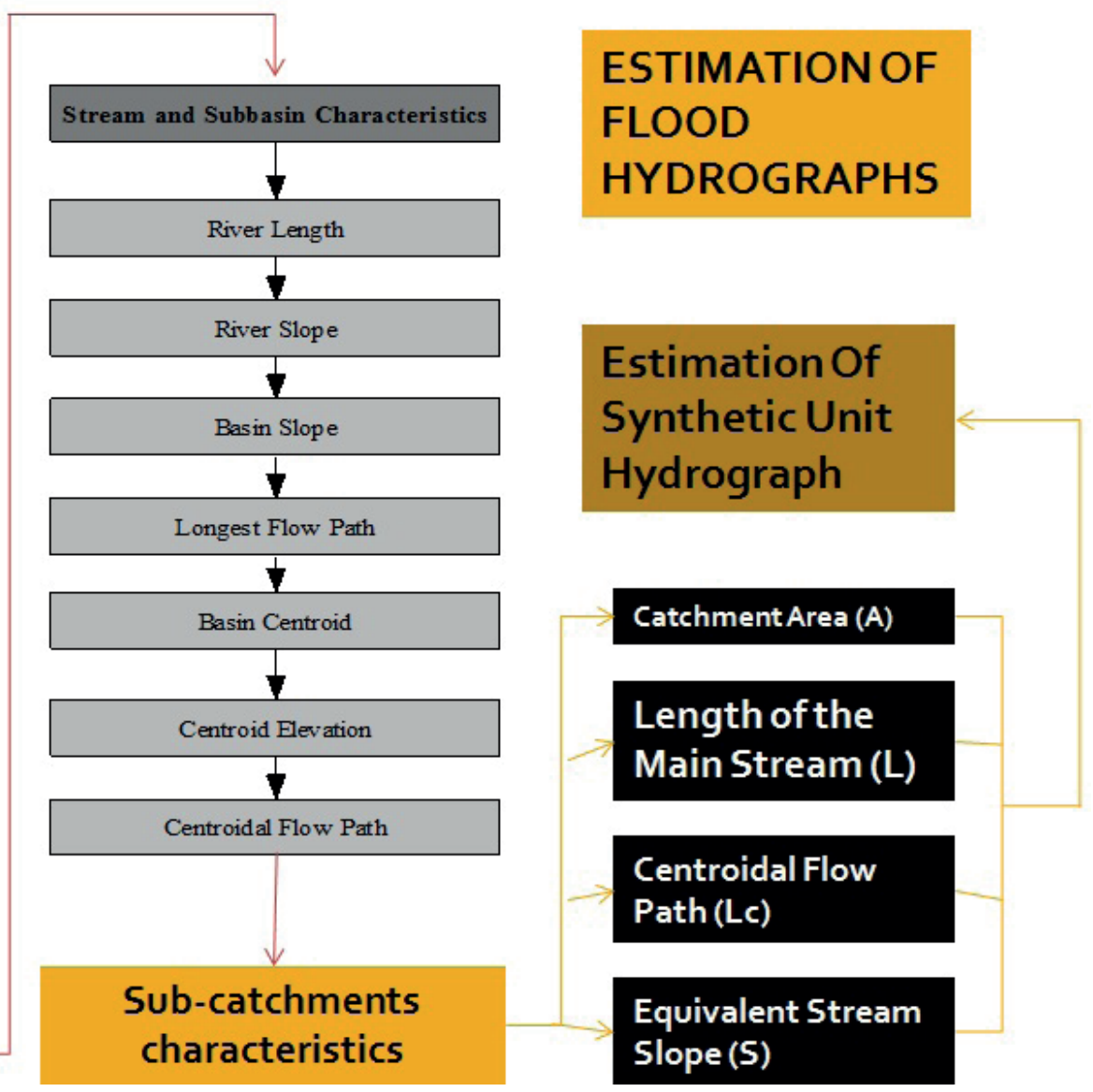

Fig. 3. Flow chart of the methodology 
computed. The centroidal flow path tells us the aspect of the flow path from basin Centroid to outlet for a basin. For this process, the values of the longest flow path, basin Centroid, and sub-basin layer are used because this parameter gives a hydrological significance to estimate design flood and storm flood.

\section{Estimation of Synthetic Unit Hydrograph}

SUH is the unit hydrograph of unit duration for a basin developed from relation established between physiographic and unit hydrograph parameters of the representative gauged basins in a hydrometeorological homogeneous region (subzones). In this approach, the design storm after converting it into effective rainfall (input) is applied to the unit hydrograph (transfer function) to obtain a design flood (basin response). It is possible to develop unit hydrograph if site-specific concurrent rainfall-runoff data is available for 5-8 years or few selected severe storm events. The collection of adequate concurrent rainfall-runoff data for every site is, however, neither practicable nor economically feasible. In such a situation, the regional method for developing SUH is advisable. Hence, in this case, the SUH is developed using procedures described in the CWC report (2002) for subzone3(c).

\section{Physiographic Parameters}

The physiographic parameter considered in the present study is basin area (A), length of the mainstream $(L)$, length of the mainstream from a point nearest to the center of gravity of the basin area to the observation site $\left(L_{c}\right)$ and the equivalent stream slope (S). The parameters for each subbasin are extracted from the HEC-Geo HMS (HEC-GeoHMS Reference Manual 2010; Parhi et al. 2012). The upstream and downstream elevation and slope are added to the river layer's attribute table with the column headings: «ElevUP», «ElevDS», and «Slp».

\section{Derivation of One Hour Unit Hydrograph}

The following parameters of SUH are estimated from the derived physiographic parameters (NIH 1997):

1. Time from the center of unit excess rainfall to the peak of unit hydrograph in hours (Tp)

$$
T p=0.995\left(\frac{L L c}{\sqrt{s}}\right)^{0.2654}
$$

2. Peak discharge of unit hydrograph in cubic meters per second (Qp).This the product of peak discharge per sq.km (qp) and basin area (A)

$$
Q p=q p * A
$$

3. The base width of unit hydrograph in hours (Tb)

$$
T B=5.04537(t p)^{0.71637}
$$

4. Width of unit hydrograph measured at discharge ordinates equal to 50\% of Qp in hours (W50).

$$
W 50=1.9145(q p)^{-1.2582}
$$

5. Width of unit hydrograph measured at discharged ordinates equal to 75\% of Qp (W75).

$$
W 75=1.1102(q p)^{-1.2088}
$$

6. Width of the rising site of unit hydrograph measured in hours at discharge ordinates equal to $50 \%$ of Qp (WR50)

$$
W R 50=0.7060(q p)^{-1.3859}
$$

7. Width of the rising site of unit hydrograph measured in hours at discharge ordinates equal to 75\% of Qp (WR75).

$$
W R 75=0.45314(q p)^{-1.3916}
$$

8. Time from the start of the rise to the peak of the unit hydrograph (Tm). This is the summation of $\mathrm{Tp}$ and $0.5^{*} \mathrm{Tr}$ where $\mathrm{Tr}$ is the unit duration of unit hydrograph

$$
T m=t p+\frac{t r}{2}
$$

9. Peak discharge of unit hydrograph per unit area in cumec per sq.km

$$
q p=1.665(t p)^{-0.71678}
$$

1-hour $U H$ is plotted using the estimated parameters $\left(T_{m^{\prime}}\right.$ TB, Qp, W50, w75, WR50 and WR75). While plotting the unit hydrograph the sum of discharge ordinates of 1-hr is obtained and compared with the theoretical value found by using the following general equations:

$$
\sum Q i=\frac{[2.78 * A]}{t r}
$$

Where, Qi= Discharge ordinates at 1-Hour interval (cumec), $A=$ basin area in sq. $\mathrm{km}$ and $\mathrm{tr}=$ unit duration in hours. Suitable adjustment is made in the falling limb region from W50 point to the tail of the $\mathrm{UH}$ and a smooth curve is drawn to make the volume equal to the volume of the $\mathrm{UH}$.

\section{Estimation of Flood Hydrographs}

The flood hydrographs for various return periods (25, 50, 100 years) were estimated for rainfall for corresponding return periods as provided in the CWC (2002) report. Other input parameters required for deriving flood hydrograph are discussed below. Design Loss Rate- Conversion of gross storm rainfall units into effective rainfall units for application to unit hydrograph is normally done by subtraction of constant rate for the basin, even though the loss rate in the basins is complex phenomena, varying due to soil conditions, soil cover and topology along with temporal and spatial variations of storm rainfall. There can be a wide variation in the loss rate. Because the estimation of basin rainfall depends upon the location of the rain gauge stations, which also affects the estimation of the areal rainfall depth for runoff observed at the outlet of the basins. So design loss rate of $0.10 \mathrm{~cm} / \mathrm{hr}$ for subzone-3(c) is used in this study. CWC (2002) has analyzed a total of 172 flood events for estimating base flow. The recommended value of the base flow of 0.05 cumec per sq. km for subzone-3(c) is used in this study. Design Storm Duration-The The duration of storm rainfall which causes maximum discharge in a drainage basin is called design storm duration. The design storm $\left(T_{d}\right)$ is estimated as $T_{d}=1.1 \times t_{p}$. Where tp is basin lag time.

\section{Time Distribution Curves}

These curves can be used to derive the time distribution co-efficient of storm rainfall in the subzone for the rainstorm of any duration. The applied method was validated by CWC in its 2002 report.

\section{Conversion of Point to Areal Rainfall}

The areal reduction factors (ARF) are factors which when applied to point rainfall values for a specified duration and return period give areal rainfall for the same duration and return period. The areal to point rainfall ratios versus basin area for design storm duration of different periods was validated by CWC in its 2002 report. The areal to point rainfall ratio is also called Areal Reduction Factor (ARF).

\section{RESULT AND DISCUSSION}

\section{HEC-HMS Model Application}

Hydrologic modeling software has been developed for simulation of the precipitation-runoff process of the 
dendritic basin system. By using its components like basin model manager and meteorological model manager a hydrologic response is computed. By using its model manager component the element of the basin is settled including subbasin, reach and junction. A model component gives the environment to set up the main feature of a basin. Background map for basin is taken as a shapefile, output of the HEC-Geo HMS project (HEC-GeoHMS Reference Manual 2010; Parhi et al. 2012). The sub-basin element is used to show physical basin. The outflow is computed by using precipitation, loss rate, and base flow. Five sub-basins are created. And four junctions are settled at the junction point of the river network for five subbasins. After setting up the model component, meteorological data is filled. By using synthetic unit hydrograph ordinates and storm rainfall values flood hydrograph for 100, 50 and 25 years are computed in HEC-HMS by setting all the data in HEC-Geo HMS components (HEC-GeoHMS Reference Manual 2010; Parhi et al. 2012).

In meteorological models specified hyetograph method is selected for all five basins. Flood hydrograph is derived for the one-hour interval for dated 25 January 2010 to 26 January 2010. For rainfall data, precipitation gages method is adopted for five basins. All the values of storm rainfall in gages one to five are given in the table.

\section{Basins Delineation and Characteristics}

By using HEC-GeoHMS model a total 57 sub-basins from the DEM are delineated. After terrain processing, the sub-basins are merged and subdivide to 5 major basins as shown in fig. 5. The total area of the basin is found to be $15032.73 \mathrm{sq} \mathrm{km}$. The basins characteristics required for deriving SUH are given in table 1.

\section{Synthetic Unit Hydrographs}

Using the relationships derived in CWC (2002) report the SUH parameters are estimated from basin characteristics. These parameters are given in Tables 2 and 3. The 1 hour-UH (unit hydrograph) for all five basins are also plotted using these parameters (Fig. 6).

\section{Estimation of design rainfall}

After the estimation of the synthetic unit hydrograph, flood hydrographs are computed for the various return periods. At the beginning of depth duration frequency analysis, design storm duration is computed using $T_{d}=1.1 \times t_{p}$ for all five basins for 25 , 50 , and 100 years given in table 2 . The values of the design storm are taken rounded off to the nearest full hour. After this Point rainfall is estimated from isopluvials maps for $25,50,100$ years by using the arithmetic mean method is given in the CWC (2002) report. A conversion factor is read from CWC (2002) report for all the basins to get 25,50,100-year point rainfall for various storm duration (Td). Now 25, 50, 100-year point rainfall, thus worked out to be (conversion factor $\times$ point rainfall) for all five basins given in table 2. The next step is carried towards the areal reduction factor. The areal reduction factor is read from the CWC (2002) report corresponding to the area of all five basins given in table 2. After getting the areal reduction factor point rainfall is converted into areal rainfall. Now storm duration of 25, 50, 100 years, areal rainfall works out to be (areal reduction factor from each basin point rainfall of basin) values are given in table 3 . Further storm duration of $25,50,100$-year areal rainfall has been split into a 1-hour rainfall increment given in table 3 using the time distribution coefficient read from in CWC (2002) report. The design loss rate of $0.10 \mathrm{~cm} /$ $\mathrm{hr}$ is used to get effective hourly rainfall.

\section{Time Distribution Curve}

Using the relationship is given in CWC (2002) report time distribution curve is derived for 25,50 and 100 years for all five basins. The blue line depicts the relationship between storm rainfall and storm duration for 50 years. As it is red line gives the same relation for 25 years. And a yellow line shows the 100-year relationship in storm hydrograph between storm rainfall and storm duration. The relationship of storm duration (Td) and storm rainfall is given in the table.

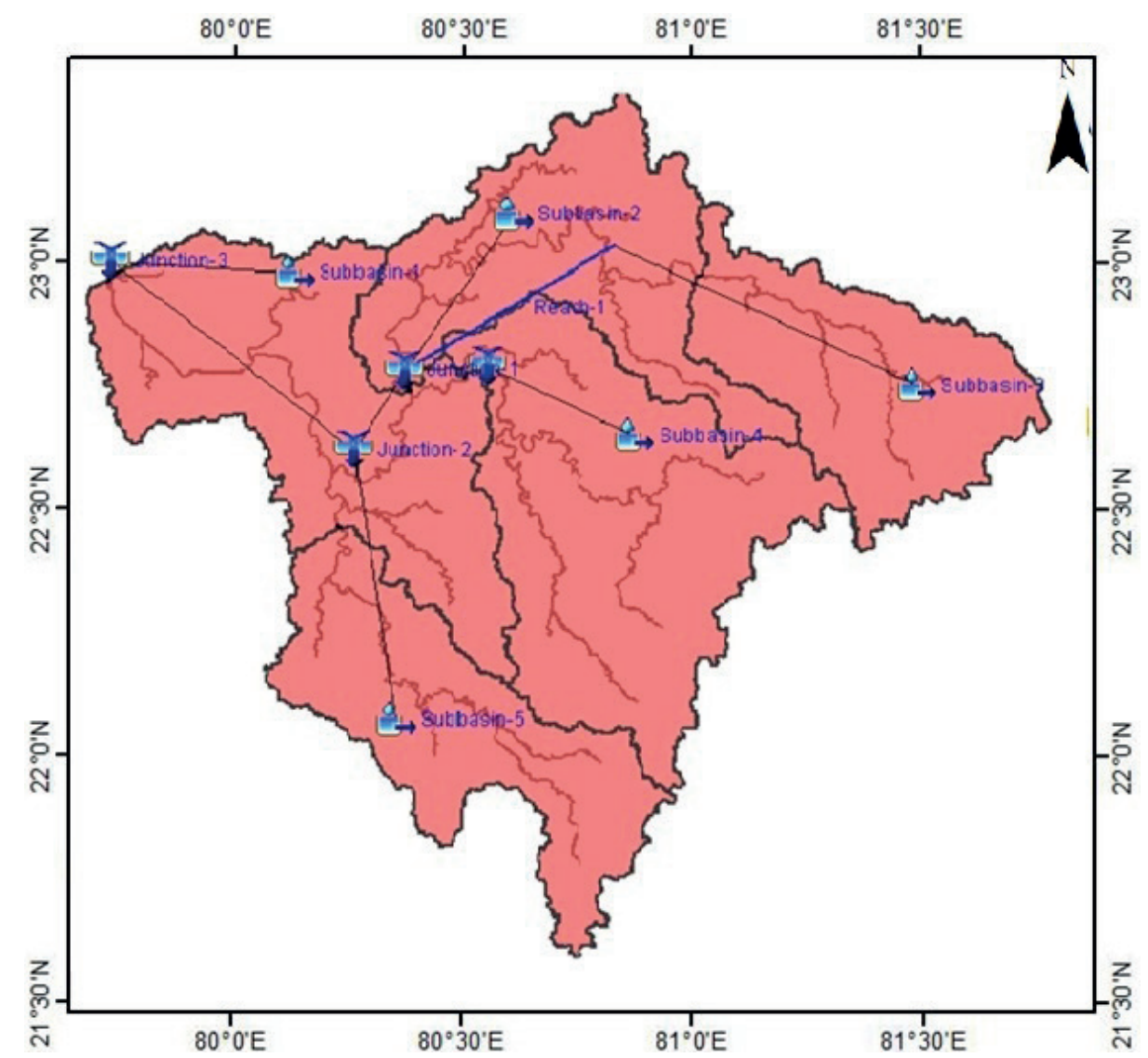

Fig. 4. HEC-GeoHMS Basin Model setup 


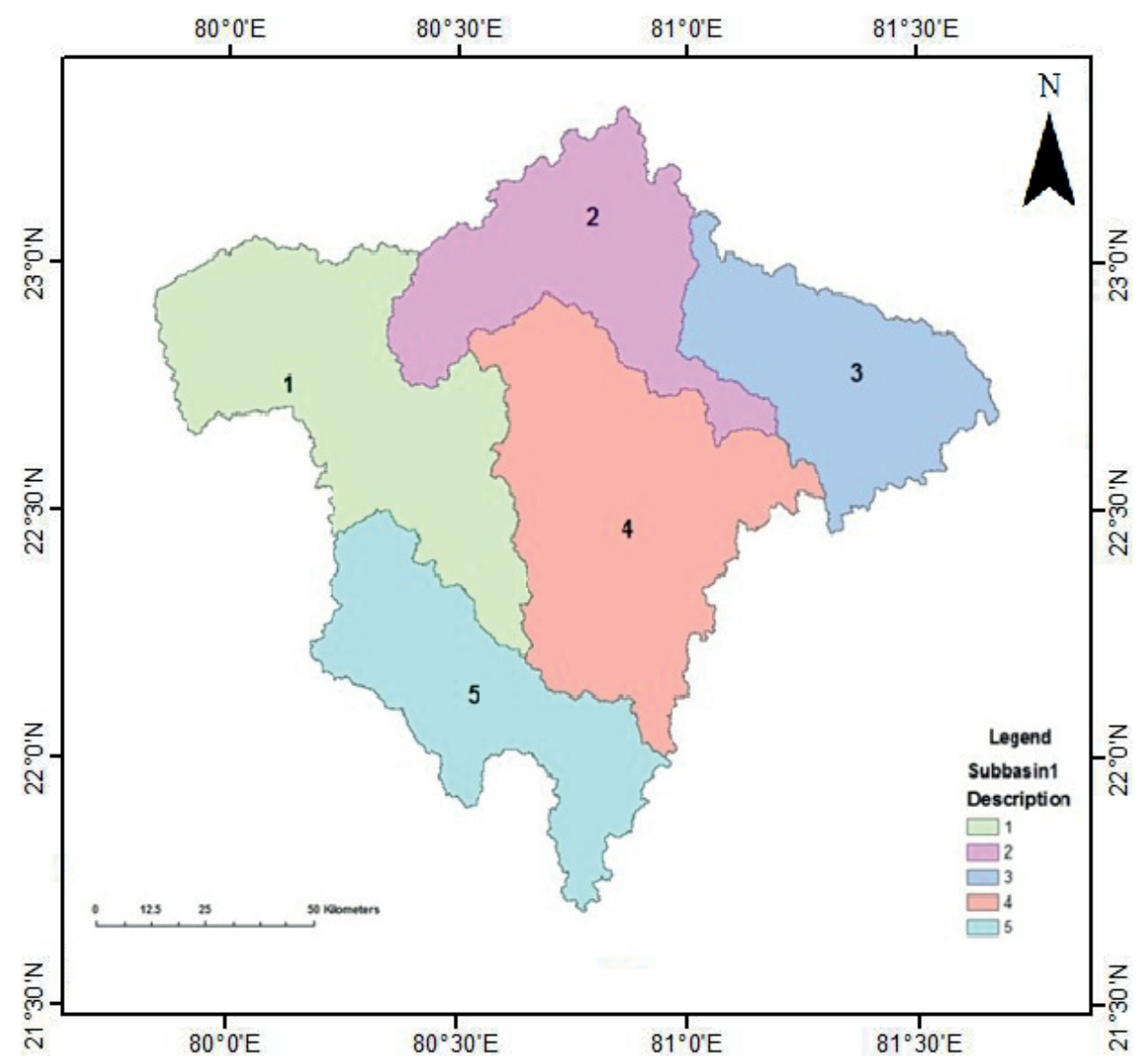

Fig. 5. Five major sub-basins

Table 1. Sub-Basins characteristics

\begin{tabular}{|l|c|c|c|c|}
\hline Sub basin No. & Basin Area $(A)\left(\mathrm{km}^{2}\right)$ & Length $(\mathrm{L})(\mathrm{km})$ & Centroidal Longest Flow Path $(\mathrm{Lc})(\mathrm{km})$ & Equivalent Slope $(\mathrm{S})(\mathrm{m} / \mathrm{km})$ \\
\hline & $3,596.30$ & 170.72 & 66.86 & 2.53 \\
\hline & $2,612.27$ & 206.88 & 97.65 & 2.59 \\
\hline & $2,311.98$ & 111.00 & 55.47 & 2.77 \\
\hline & $3,978.36$ & 173.33 & 88.83 & 2.59 \\
\hline & $2,533.82$ & 172.60 & 91.52 & 1.47 \\
\hline
\end{tabular}

Table 2. Parameters of unit hydrograph

\begin{tabular}{|c|c|c|c|c|c|}
\hline \multirow{2}{*}{ Parameters } & \multicolumn{5}{|c|}{ Basin No. } \\
\hline & 1 & 2 & 3 & 4 & 5 \\
\hline $\begin{array}{l}\text { Time from the center of unit excess rainfall to the peak of unit hydrograph in } \\
\qquad \text { hours }(T p)\end{array}$ & 10.5 & 12.5 & 8.5 & 11.5 & 12.5 \\
\hline Base width of unit hydrograph in hours (Tb) & 27.19 & 30.24 & 23.97 & 28.71 & 30.45 \\
\hline Peak discharge of unit hydrographs (Qp) $\left(\mathrm{m}^{3} / \mathrm{s}\right)$ & 1,110 & 724.89 & 809.42 & $1,162.5$ & 698.16 \\
\hline $\begin{array}{l}\text { Width of unit hydrograph measured at discharge ordinates equal to 50\% of } \\
\qquad \text { Qp in hours (W50) }\end{array}$ & 8.4 & 9.6 & 7.17 & 9.001 & 9.69 \\
\hline $\begin{array}{l}\text { Width of unit hydrograph measured at discharge ordinates equal to } 75 \% \text { of } \\
\qquad \text { Qp in hours (W75) }\end{array}$ & 4.59 & 5.22 & 3.94 & 4.91 & 5.27 \\
\hline $\begin{array}{l}\text { Width of the rising site of unit hydrograph measured in hours at discharge } \\
\text { ordinates equal to 75\% of Qp (WR75) }\end{array}$ & 2.32 & 2.69 & 1.95 & 2.51 & 2.72 \\
\hline $\begin{array}{l}\text { Width of the rising site of unit hydrograph measured in hours at discharge } \\
\text { ordinates equal to 50\% of Qp (WR50) }\end{array}$ & 3.6 & 4.17 & 3.02 & 3.88 & 4.21 \\
\hline Peak discharge of unit hydrograph per unit area of basin (qp) $\left(\mathrm{m}^{3} / \mathrm{s} / \mathrm{km}^{2}\right)$ & 0.3 & 0.27 & 0.35 & 0.29 & 0.27 \\
\hline Time from the start of the rise to the peak of the unit hydrograph (Tm) & 11 & 13 & 9 & 12 & 13 \\
\hline Discharge ordinates at 1-Hour interval (Qi) (cumec) & $9,990.5$ & $7,256.9$ & $6,422.7$ & 11,052 & 7,039 \\
\hline
\end{tabular}


Table 3. Storm Hydrograph parameters for five basins for 100, 50, 25-year storm rainfall

\begin{tabular}{|c|c|c|c|c|c|c|c|c|c|c|c|c|c|c|c|}
\hline Return period for & \multicolumn{9}{|c|}{100 year } & \multicolumn{4}{|c|}{50 year } & \multicolumn{3}{|c|}{25 year } \\
\hline C. No. & 1 & 2 & 3 & 4 & 5 & 1 & 2 & 3 & 4 & 5 & 1 & 2 & 3 & 4 & 5 \\
\hline Storm duration (Td) & 12 & 14 & 10 & 13 & 14 & 12 & 14 & 10 & 13 & 14 & 12 & 14 & 10 & 13 & 14 \\
\hline Conversion factor & 0.79 & 0.84 & 0.76 & 0.82 & 0.84 & 0.79 & 0.84 & 0.76 & 0.82 & 0.84 & 0.79 & 0.84 & 0.76 & 0.82 & 0.84 \\
\hline Mean rainfall & 25.33 & 22 & 22 & 20 & 26 & 28 & 24 & 24 & 22 & 29 & 32 & 28 & 26 & 28 & 34 \\
\hline Point rainfall & 20.01 & 18.48 & 16.72 & 16.4 & 21.84 & 22.12 & 20.16 & 18.24 & 18.04 & 24.36 & 25.28 & 23.52 & 19.76 & 22.96 & 28.56 \\
\hline Areal reduction factor & 0.67 & 0.64 & 0.63 & 0.60 & 0.65 & 0.67 & 0.64 & 0.63 & 0.60 & 0.65 & 0.67 & 0.64 & 0.63 & 0.60 & 0.65 \\
\hline 1Hour rainfall & 13.41 & 11.82 & 10.53 & 9.84 & 14.19 & 14.82 & 12.90 & 11.49 & 10.82 & 15.83 & 16.94 & 15.05 & 12.44 & 13.77 & 18.56 \\
\hline
\end{tabular}

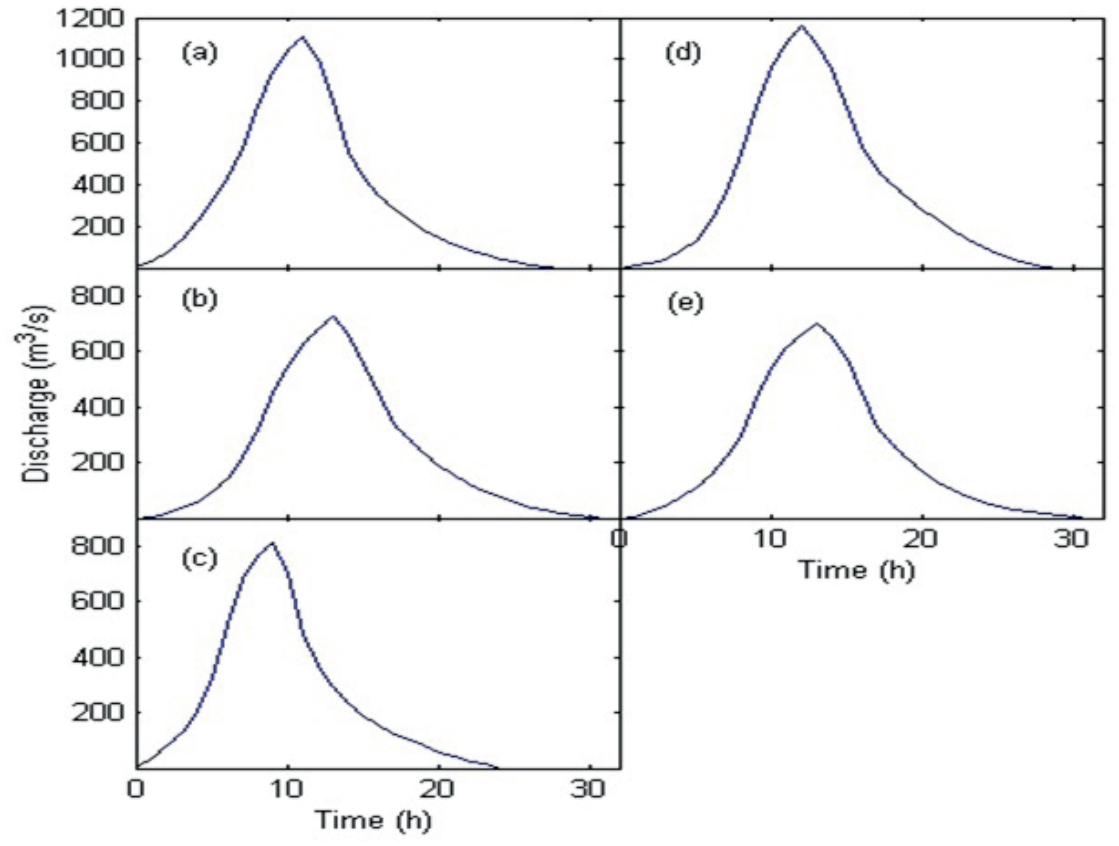

Fig. 6. Estimated SUH for five sub-basins
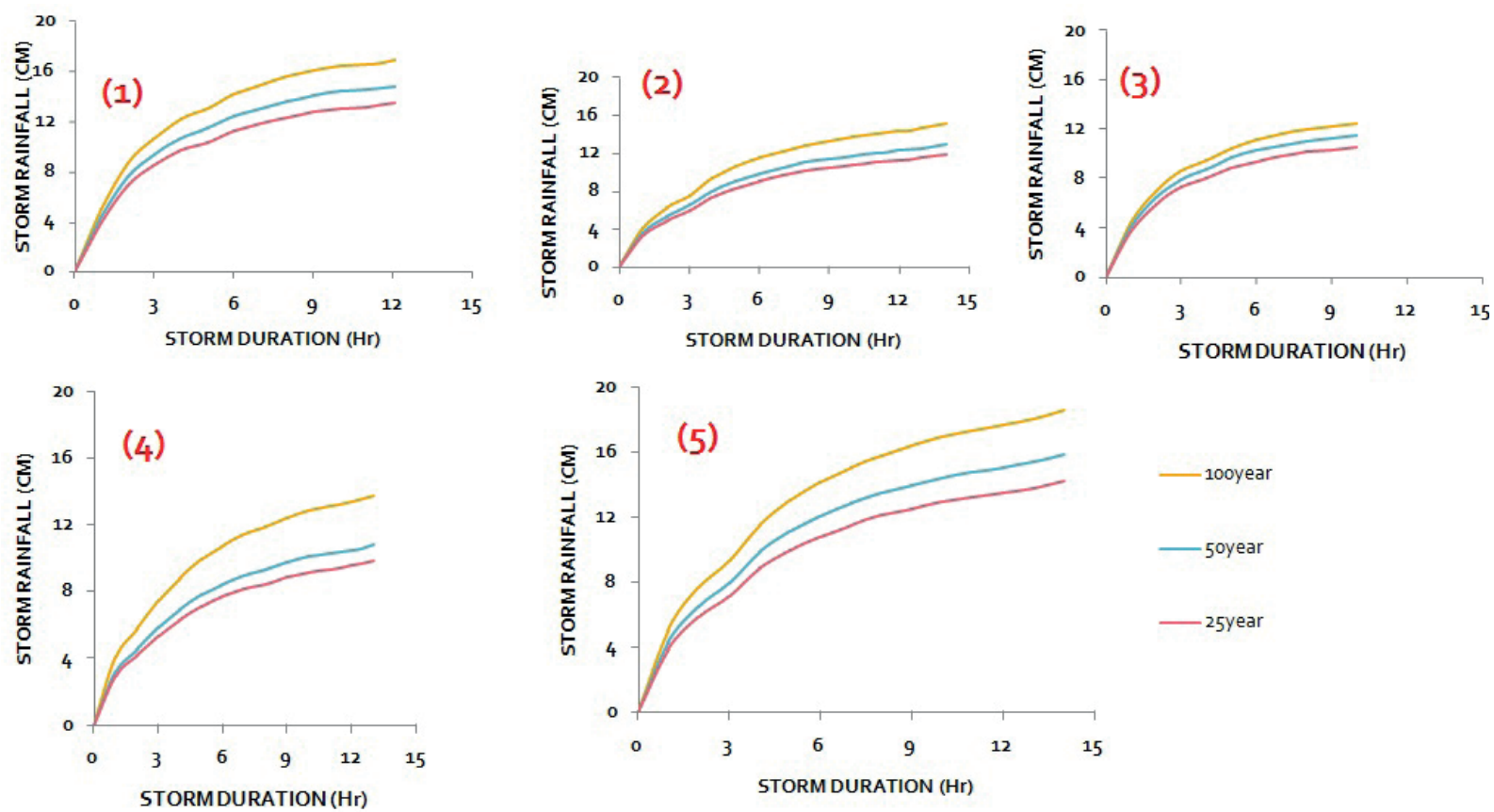

Fig. 7. Time distribution curve for five basins for 25,50 and 100 years

Flood Hydrographs

After computing the simulation process the result is gathered at junction three. The results of the simulation also present the individual result of sub-basins, junctions and reach also. Subbasin-1 gives peak discharge at 14160.6 cumec at 12:00. Subbasin-2 contributes peak discharge at 7526.6 cumec at 14:00. Subbasin-3 is giving 7,564.5 cumec peak discharge at 10:00. At Subbasin-4 peak, discharge is 11024.2 cumec at 14:00 and at subbasin-5 it is 9288.1 cumec at 15:00. 

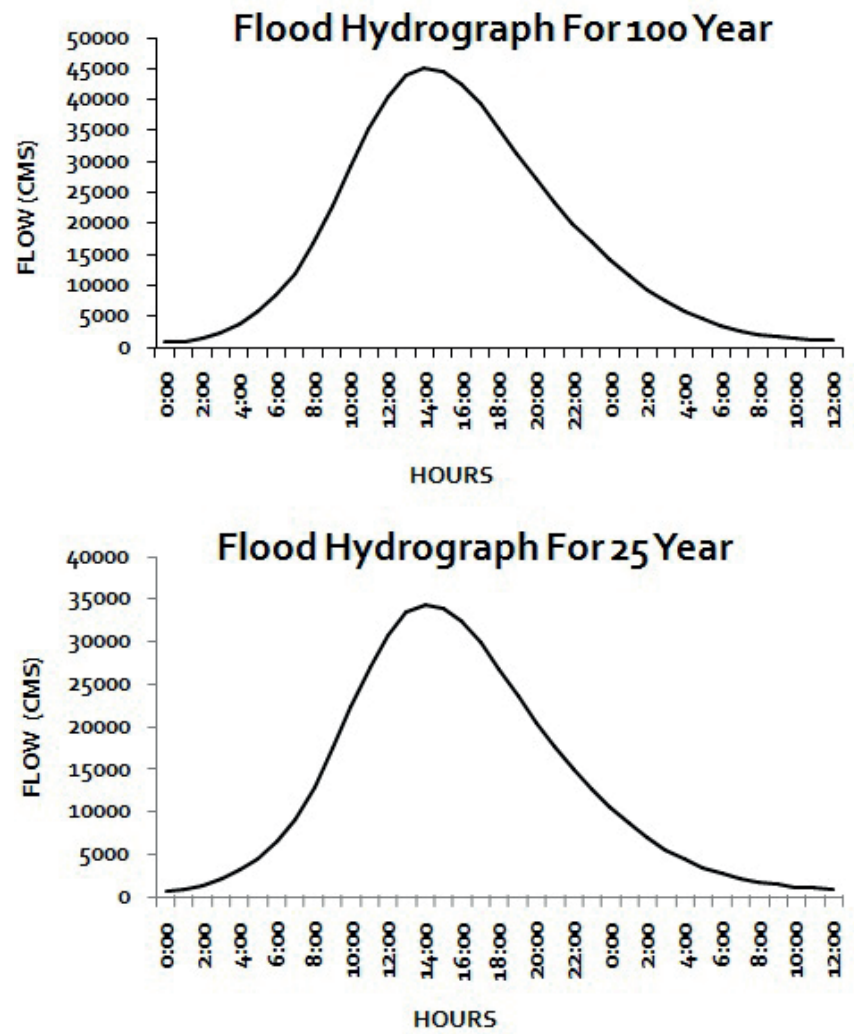

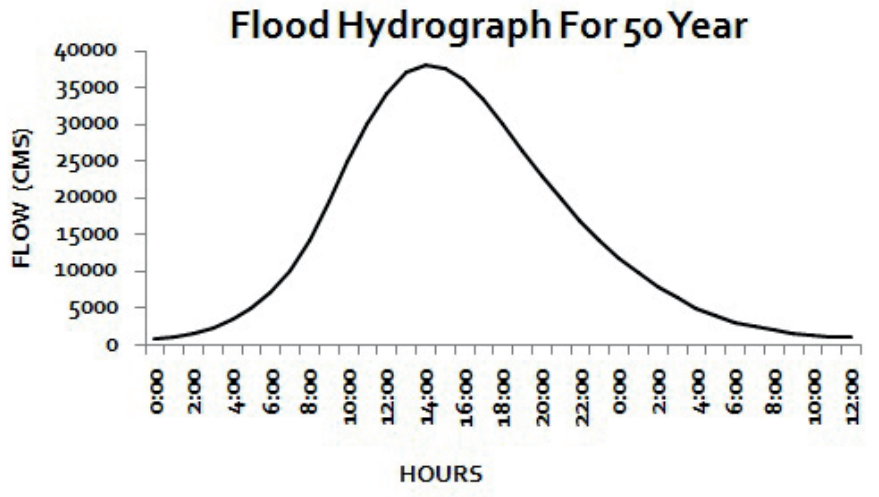

HOURS

Fig. 8. Flood Hydrographs for 25, 50 and 100 years

Flood hydrograph for 100 years

The result at junction three depicts the peak outflow is 45004.7 cumec and the total outflow is $147.24(\mathrm{~mm})$. The peak outflow is computed on dated 25 January 2010 at time 14:00. In fig. 7 flood hydrograph depicts outflow at junction-3 which has the contribution of junction-2 and subbasin-1. At Junction-1, 2, 3, 4 peak flow is 24,515.3; 33,803.4; 45,004.7; 11,024.2 cumec respectively. The rising limb of the 100year flood hydrograph at starting hour 00:00 to 07:00 hour shows the normal flow of the river (Fig. 8). After 07:00 hours outflow is increasing and outflow is above 10,000 cumec. At 14:00 hours outflow reaches peak discharge 45,004.7 cumec. Recession limb starts after 14:00 hours and it is continuously decreasing up to 04:00 hours shown in the table. After 04:00 hour to 12:00 hour, it is rapidly decreased.

\section{Flood hydrograph for 50 years}

The result of the flood hydrograph of 50 years gives the peak outflow 38012.2 cumec at 14:00 hours and the total outflow is $124.59 \mathrm{~mm}$ at junction-3. Starting 3 hours of rising limb shows the general flow of the river and from 04:00 to 14:00 hours it depicts the rising side of discharge. The peak discharge is $38,012.2$ cumec at 14:00 hours. After 14:00 hours decreasing limb starts and it goes up to 04:00 hours with a great recession rate and then 04:00 to 12:00 hours it decreases with average rate. These time-series data are shown in table 3.

\section{Flood hydrograph for 25 years}

Junction-3 is the main outlet of all discharges. So at junction-3 peak discharge is 34,326 cumec. Discharge from subbasin-1 is 11,109.5 cumec and at a junction, it is 25,625.9 cumec. Discharge from these two elements reaches junction-3. And discharge from subbasin-2, 3, 4 and 5 is $5,840.6 ; 6,355.7 ; 7,722.8 ; 7,016.2$ cumec respectively. Flood hydrograph of 25 years has a peak value of 34326 cumec at 14:00 hours. And the total outflow is $112.54 \mathrm{~mm}$. Starting the first hour has a normal discharge value of 944.4 cumec from 02:00 hour to 14:00 hour rising limb is increasing with rapid speed. And 14:00 hour to 07:00 hour recession limb have also the rapid rate of discharge but from 06:00 to 12:00 discharge rate is normal.

\section{CONCLUSIONS}

This study utilized a hydro informative approach to analyze design flash flood for better understanding of flood control to provide safety for a proposed project site and mitigating flood hazard. The flood hydrograph for various periods were analyzed in an ungauged basin, and the simulation results were satisfactory. The Geospatial analysis techniques which are used in combination of HECHMS and HEC-GeoHMS are practical for obtaining basin topographic parameters as well as it makes hydrological forecast more reliable and demonstrated high simulation accuracy in the basin. The flood volume and timing along with peak discharge predicted fairly accurate. It is observed that the application of HEC-HMS should be expectant to corroborate its suitability for the Indian basins. 


\section{REFERENCES}

Bernard M. (1935). An approach to determinate stream flow. Transactions of the American Society of Civil Engineers, 100, $347-362$. Bhaskar N.R., Parida B.P. and Nayak A.K. (1997). Flood estimation for ungauged catchments using the GIUH. Journal of Water Resources Planning and Management, 123 (4), 228-238, DOI: 10.1061/(ASCE)0733-9496(1997)123:4(228). 43-69.

Boyd M.J. (1979). A storage-routing model relating drainage basin hydrology and geomorphology. Hydrological Sciences Bulletin, 24,

Boyd M.J., Pilgrim D.H. and Cordery I. (1979). A storage routing model based on catchment geomorphology. Journal of Hydrology, 42 (3-4), 209-330.

Central Water Commission (CWC). (2002). Flood Estimation Report for Upper Narmada and Tapi subzone-3(c) (revised), 5-28.

Central Water Commission (CWC). (2010). Development of Hydrological Design Aids project (Surface Water) under HP-II. [online].

Available at: www.cwc.nic.in/Training_Workshop_in_CWC/Hydrology_Workshop_Feb\%206-7,06.pdf [Accessed 24 October 2011].

Clark C.O. (1945). Storage and unit hydrograph. Transactions of the American Society of Civil Engineers, 110, 1419-1446.

Giuliano D.B, Francesco L.B and Alberto M.C. (2009). Design flood estimation using model selection criteria, Physics and Chemistry of the Earth, 34, 10-12.

Janusz Zelazinski (1986). Application of the geomorphological instantaneous unit hydrograph theory to the development of forecasting model in Poland, Hydrological Science Journal, 31, 2, 6/1986.

Jenson S.K. and Domingue J.O. (1988). Extracting topographic structure from digital elevation data for geographic information system analysis. Photogrammetric Engineering and Remote Sensing, 54(11), 1593-1600.

Jenson S.K. (1985). Automated derivation of hydrologic basin characteristics from digital elevation model data. In: Proceedings of the digital representations of spatial knowledge (Auto-Carto 7), 11-14 March, Washington, DC. Falls Church, VA: American Society for Photogrammetry and American Congress on Surveying and Mapping, 301-310.

Maidment D. (2002). ArcHydro-GIS for water resources. Redlands, CA: ESRI Press, 220.

Maidment D.R., et al. (1996). Unit hydrograph derived from a spatially distributed velocity field. Hydrological Processes, 10, $831-$ 844, DOI: 10.1002/(SICI)1099-1085(199606)10:6\&lt;831::AID-HYP374\&gt;3.0.CO;2-N.

Minshall N.E. (1960). Predicting storm runoff on small experimental watersheds. J. Hydraul. Div. Am. Soc. Civ. Eng., 86 (HY 8), 17-38.

Mediero L., Jiménez-Alvarez A. and Garrote L. (2010). Design flood hydrographs from the relationship between flood peak and volume, Hydrol. Earth Syst. Sci., 14, 2495-2505.

Nash J.E. (1957). The form of the instantaneous unit hydrograph. Hydrological Sciences Bulletin, 3, 114-121.

National Institute of Hydrology $(\mathrm{NIH})$. (1997). Rainfall-runoff modelling of morel catchment for design flood estimation. [online]. Available at: www.nih.ernet.in/TechnicalPapers/Rainfall_runoff_modelling_of_morel_catchment_for_design_flood_estimation_NIH_199798.pdf [Accessed 24 October 2011].

National Institute of Hydrology $(\mathrm{NIH})$. (1998). Application of GIUH, and GIS-Based Approach for Design Flood Estimation Report. [online]. Available at: www.nih.ernet.in/TechnicalPapers/Application_of_GIUH_and_GIS_Based_Approach_for_Design_Flood_Estimation.pdf [Accessed 24 October 2011].

Nakamura S., Oki T. (2018). Paradigm shifts on flood risk management in Japan: Detecting triggers of design flood revisions in the modern era. Water Resour. Res. 54 (8), 5504-5515.

Olivera F. and Maidment D.R. (1999). GIS tools for HMS modeling support. Proceedings of the 19th ESRI users conference, July 26-30, San Diego, CA.

Parkes B., Demeritt D. (2016). Defining the hundred year flood: A Bayesian approach for using historic data to reduce uncertainty in flood frequency estimates. J. Hydrol. 540, 1189-1208.

Panigrahi R.K. (1991). «Derivation of nash model parameters from geomorphological instantaneous unit hydrograph» M.E. Dissertation,

DOH, UOR, Roorkee, India.

Parhi P.K., Sankhua R.N. and Roy G.P. (2012). Calibration of Channel Roughness for Mahanadi River, (India) Using HEC-RAS Model. Journal of Water Resource and Protection 04(10), 847-850, DOl: 10.4236/jwarp.2012.410098.

Rodríguez-lturbe I. and Rinaldo A. (1997). Fractal river basins; chance and self-organization. Cambridge University Press.

Rodríguez-Iturbe I. and Valdés J. (1979). The geomorphologic structure of the hydrologic response. Water Resources Research, 15(6), 1409-1420, DOI: 10.1029/WR015i006p01409.

Rodríguez-Iturbe I., GonzBlez-Sanabira M. and Caamaño G. (1982b). On the climatic dependence of the IUH: a rainfall runoff analysis of the Nash model and the geomorpho-climatic theory. Water Resources Research, 18(4), 887-903, DOI: 10.1029/WR018i004p00887.

Rowe T.J and Smithers J.C. (2018). Continuous simulation modelling for design flood estimation - a South African perspective and recommendations. Water SA, Pretoria, 44(4), 691-705.

Rosbjerg D. et al. (2013). Prediction of floods in ungauged basins, in Runoff Prediction in Ungauged Basins. A Synthesis Across Processes, Places and Scales, edited by G. Bloschl, et al., 189-226, Cambridge Univ. Press: Cambridge, U.K.

Rogger M., Kohl B., Pirkl H., Viglione A., Komma J., Kirnbauer R., Merz R. and Bloschl G. (2012). Runoff models and flood frequency statistics for design flood estimation in Austria—Do they tell a consistent story?, J. Hydrol., 456, 30-43, DOl: 10.1016/j.jhydrol.2012.05.068.

Smith B. and Sandwell D. (2003). Accuracy and resolution of shuttle radar topography mission data. Geophysical Research Letters, 30(9), 1467.

Snyder F.F. (1938). Synthetic unit-graphs. Transactions American Geophysical Union, 19, 447-454, DOI: 10.1029/TR019i001 p00447.

Sauquet E., Ramos M.H., Chapel L., Bernardara P. (2008). Stream flow scaling properties: investigating characteristic scales from different statistical approaches. Hydrol. Process 22(17), 3462-3475, DOI: 10.1002/ hyp.6952

Serinaldi F. and Grimaldi S. (2011). Synthetic design hydrographs based on distribution functions with finite support, J. Hydrol. Eng., 16, 434-446.

Smithers J.C. (2012). Methods for design flood estimation in South Africa, Water SA, 38, 633-646.

Taylor A.B. and Schwarz H.E. (1952). Unit hydrograph lag and peak flow related to basin characteristics. Transactions, American Geophysical Union, 33, 235-246, DOI: 10.1029/TR033i002p00235.

US Army Corps of Engineers, HEC-GeoHMS, Hydraulic Reference Manual Version 4.1, 2010: Hydrologic Engineering Center.

WRIS. (2012). River Basin atlas of India, Publication of Ministry of Water Resources, Government of India, jointly created by Central Water Commission (CWC) and Indian Space Research Organization (ISRO) under India WRIS project, 144. 
(WMO) World Meteorological Organization. (2009). Extreme Values Analysis in: The Guide to Hydrological Practices. Volume II: Management of Water Resources and Application of Hydrological Practicesю [online]. Available at: www.whycos.org/hwrp/guide/index.php [Accessed 25 May 2020].

Xiao Y., Guo S., Liu P., Yan B. and Chen L. (2009). Design flood hydrograph based on multi characteristic synthesis index method, J. Hydrol. Eng., 14(12), 1359-1364.

Yen B.C. and Lee K.T. (1997). Unit hydrograph derivation for ungauged watersheds by stream order laws. Journal of Hydrologic Engineering, 2(1), 1-9, DOI: 10.1061/(ASCE)1084-0699(1997)2:1(1).

Yue S., Ouarda T., Bobee B., Legendre P. and Bruneau P. (2002). Approach for describing statistical properties of flood hydrograph, J. Hydrol. Eng., 7(2), 147-153. 